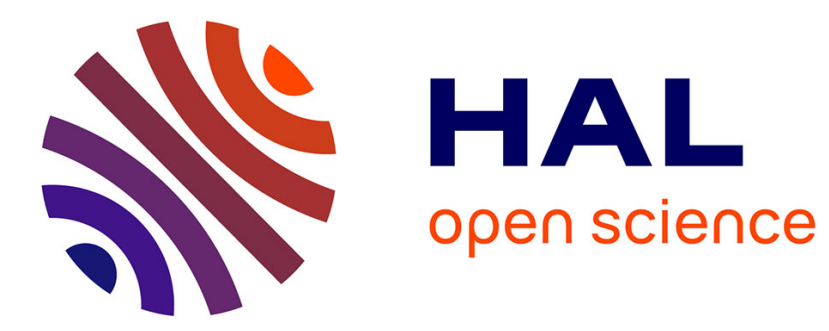

\title{
Effects Of Temperature On Cellular And Biochemical Parameters In The Crab Carcinus Aestuarii (Crustacea, Decapoda)
}

\author{
Valerio Matozzo, Chiara Gallo, Maria Gabriella Marin
}

\section{- To cite this version:}

Valerio Matozzo, Chiara Gallo, Maria Gabriella Marin. Effects Of Temperature On Cellular And Biochemical Parameters In The Crab Carcinus Aestuarii (Crustacea, Decapoda). Marine Environmental Research, 2011, 10.1016/j.marenvres.2011.04.001 . hal-00703486

\section{HAL Id: hal-00703486 https://hal.science/hal-00703486}

Submitted on 2 Jun 2012

HAL is a multi-disciplinary open access archive for the deposit and dissemination of scientific research documents, whether they are published or not. The documents may come from teaching and research institutions in France or abroad, or from public or private research centers.
L'archive ouverte pluridisciplinaire HAL, est destinée au dépôt et à la diffusion de documents scientifiques de niveau recherche, publiés ou non, émanant des établissements d'enseignement et de recherche français ou étrangers, des laboratoires publics ou privés. 


\section{Accepted Manuscript}

Title: Effects Of Temperature On Cellular And Biochemical Parameters In The Crab

Carcinus Aestuarii (Crustacea, Decapoda)

Authors: Valerio Matozzo, Chiara Gallo, Maria Gabriella Marin

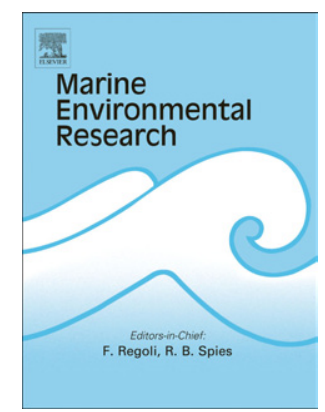

PII:

S0141-1136(11)00044-4

DOI:

10.1016/j.marenvres.2011.04.001

Reference: MERE 3517

To appear in: Marine Environmental Research

Received Date: 24 February 2011

Revised Date: 6 April 2011

Accepted Date: 8 April 2011

Please cite this article as: Matozzo, V., Gallo, C., Marin, M.G. Effects Of Temperature On Cellular And Biochemical Parameters In The Crab Carcinus Aestuarii (Crustacea, Decapoda), Marine Environmental Research (2011), doi: 10.1016/j.marenvres.2011.04.001

This is a PDF file of an unedited manuscript that has been accepted for publication. As a service to our customers we are providing this early version of the manuscript. The manuscript will undergo copyediting, typesetting, and review of the resulting proof before it is published in its final form. Please note that during the production process errors may be discovered which could affect the content, and all legal disclaimers that apply to the journal pertain. 
Effects of temperature on cellular and biochemical parameters in the crab

Carcinus aestuarii (Crustacea, Decapoda)

3

4 Valerio Matozzo*, Chiara Gallo, Maria Gabriella Marin

5

6

Department of Biology, University of Padova, Via Ugo Bassi 58/B, 35131 Padova (Italy)

8

9

10

$11 *$ Correspondence to:

Dr. Valerio Matozzo

12

Department of Biology

13

University of Padova

14

Via Ugo Bassi, 58/B

15

35131 Padova, ITALY

16

Phone: +39-049-8276201

17

Fax: +39-049-8276199

18

e-mail:matozzo@bio.unipd.it 
Abstract

The effects of temperature on cellular and biochemical parameters of the crab Carcinus aestuarii were evaluated. Crabs were kept for 7 days at 4,17 (reference value) and $30{ }^{\circ} \mathrm{C}$ (salinity of $35 \mathrm{psu}$ ), and total haemocyte count (THC), haemocyte volume, haemocyte proliferation, phenoloxidase (PO) activity in both haemocyte lysate (HL) and cell-free haemolymph (CFH), $\mathrm{CFH}$ total protein and glucose levels, superoxide dismutase (SOD) and catalase (CAT) activities in both gills and digestive gland were evaluated. The lowest and the highest temperature significantly decreased THC, whereas haemocyte volume and haemolymph glucose concentration did not differ significantly among experimental conditions. Haemolymph protein concentration significantly reduced in crabs maintained at $30{ }^{\circ} \mathrm{C}$, when compared with that of animals kept at 4 and $17{ }^{\circ} \mathrm{C}$. Haemocyte proliferation increased significantly in crabs kept at 4 and $30^{\circ} \mathrm{C}$, when compared with that of crabs held at $17^{\circ} \mathrm{C}$. Likewise, a significantly higher PO activity was recorded in $\mathrm{CFH}$ from crabs kept at 4 and $30{ }^{\circ} \mathrm{C}$, than in control crabs. Conversely, PO activity did not vary significantly in HL. With regard to antioxidant enzyme activities, a significant decrease in CAT activity was observed in gills from crabs kept at $4{ }^{\circ} \mathrm{C}$, when compared to that of crabs kept at $17^{\circ} \mathrm{C}$ and $30^{\circ} \mathrm{C}$. Results obtained demonstrated that the highest and lowest temperature tested influenced crab biological responses, and indicated that $C$. aestuarii modulated its cellular and biochemical parameters (mainly haemocyte proliferation, $\mathrm{CFH}$ protein concentrations and $\mathrm{CFH}$ PO activity) in order to cope with temperature.

Keywords: crabs; immune parameters; temperature; haemocytes; glucose; antioxidant enzymes 


\section{Introduction}

Crustacea have an open vascular system in which numerous haemocytes freely circulate in haemolymph. Circulating haemocytes are involved in wound repair and defence mechanisms against parasites, viruses and bacteria (Bauchau, 1981). As there are evidence that stress conditions (e.g., variations in temperature and salinity, and exposure to ammonia, sulphide and nitrite) can cause immunemodulation in Crustacea (Le Moullac and Haffner, 2000; Hong et al., 2007; Hsu and Chen, 2007; Romano and Zeng, 2009), increasing interest has recently been addressed to the evaluation of stress effects on immune functions in these invertebrates. Among environmental factors capable of influencing haemocyte-dependent defence mechanisms in Crustacea, temperature is regarded as one of the most important (Le Moullac and Haffner, 2000). For example, Truscott and White (1990) demonstrated that a gradual increase in temperature (from 10 to $20^{\circ} \mathrm{C}$ ) over a 12 h period significantly increased haemocyte number in $C$. maenas after 5 days, whereas a sudden temperature change did not cause significant alterations. In the same crab species, Chisholm and Smith (1992) observed that seasonal temperature changes affected haemocyte antibacterial activity, with the lowest activity recorded in February and August when water temperatures reached the lowest and highest value, respectively. In the brown shrimp Penaeus californiensis, exposure to increased temperature (from $18{ }^{\circ} \mathrm{C}$ to $32{ }^{\circ} \mathrm{C}$ ) affected haemolymph parameters: a decrease in haemocyte pro-phenoloxidase (proPO) system was observed at $32{ }^{\circ} \mathrm{C}$, whereas an increase in haemolymph protein content was recorded at both $28{ }^{\circ} \mathrm{C}$ and $32{ }^{\circ} \mathrm{C}$ (Vargas-Albores et al., 1998). Temperature has also been shown to negatively affect the haemocyte phagocytic activity of lobsters (Paterson and Stewart, 1973; Steenbergen et al., 1978). In the freshwater prawn Macrobrachium rosenbergii, it was observed that total haemocyte count (THC) decreased significantly in prawns kept at $33-34{ }^{\circ} \mathrm{C}$, when compared with THC of animals held at $27-28{ }^{\circ} \mathrm{C}$ and $30-31{ }^{\circ} \mathrm{C}$ (Cheng and Chen, 2000). In that study, PO activity showed significant differences at all temperatures tested, reaching the highest value at $30-31{ }^{\circ} \mathrm{C}$. 
Among decapod species, Carcinus aestuarii is particularly abundant in the Mediterranean area, and differs from the Atlantic species Carcinus maenas in morphological traits, such as the shape of the copulatory appendages (pleopods) in males, the shape of the frontal area between eyes, and the carapace width to length ratio (Yamada and Hauck, 2001). Surprisingly, Carcinus has colonised several regions outside its native ranges, including Australia, Tasmania, South Africa, Japan and both coasts of North America, probably due to their high tolerance to air exposure, starvation, and variations in temperature and salinity (Yamada and Hauck, 2001; Roman and Palumbi, 2004). Along the Italian coasts, $C$. aestuarii has also colonised estuarine areas, such as the Lagoon of Venice and the Lagoon of Orbetello. In the lagoon of Venice, fishing and farming of C. aestuarii are important economical activities: fishermen select crabs during moulting, when they lose the follows growth rates of crabs.

Like other Crustacea (Bauchau, 1981), three main haemocyte types have recently been identified in C. aestuarii: granulocytes, with evident cytoplasmic granules, semigranulocytes, with less granules than granulocytes, and hyalinocytes, without evident granules (Matozzo and Marin, 2010a). Hyalinocytes are the main phagocytic cells, whereas granulocytes show high phenoloxidase (PO) activity (Matozzo and Marin, 2010b).

In the present study, the effects of varying temperatures $\left(4,17\right.$ and $\left.30^{\circ} \mathrm{C}\right)$ on both cellular and biochemical parameters were evaluated for the first time in $C$. aestuarii. The experimental temperatures were chosen taking into account that temperature values close to those tested in this study can be recorded in the Lagoon of Venice during wintertime and summertime, respectively. In particular, the extreme temperatures tested $\left(4\right.$ and $\left.30{ }^{\circ} \mathrm{C}\right)$ can be reached in shallow waters $(<1 \mathrm{~m})$ of the lagoon, where crabs are also present. THC, haemocyte volume, haemocyte proliferation, phenoloxidase (PO) activity in both haemocyte lysate (HL) and cell-free haemolymph (CFH), and CFH total protein and glucose levels were measured. These biomarkers were chosen being 
considered as useful indicators of immunesurveillance status in Crustacea (Le Moullac and Haffner, 2000), and taking into account that a reduced immunesurveillance can strongly enhance the susceptibility of animals to infections/diseases. In addition, superoxide dismutase (SOD) and catalase (CAT) activities were measured in both gills and digestive gland of crabs maintained at the differing temperatures. SOD and CAT are antioxidant enzymes that play an important role in reducing damage to cells caused by reactive oxygen species (ROS). The aim of the present study was to evaluate whether temperature can affect both immune parameters and antioxidant enzyme activities in an ecologically and economically important crab species.

\section{Materials and methods}

\subsection{Crabs}

Intermoult adult male crabs ( $4 \mathrm{~cm}$ mean carapace length) were collected by handmade traps in the Lagoon of Venice. Crabs (50 at least) were then kept in the laboratory in large aquaria (50 L) containing seawater (salinity of $35 \pm 1 \mathrm{psu}$ and temperature of $17 \pm 0.5^{\circ} \mathrm{C}$ ) and a sandy bottom. The crabs were fed with mussels (Mytilus galloprovincialis) and acclimatised in the laboratory for 5 days before exposure to differing temperatures.

\subsection{Exposure to differing temperatures}

Prior to experimental temperature exposure, crabs were acclimatised to experimental conditions by progressively increasing or decreasing seawater temperature $\left(2-2.5^{\circ} \mathrm{C}\right.$ per day) in the aquaria (50 L) to 4 and $30{ }^{\circ} \mathrm{C}$. Crabs maintained at $17{ }^{\circ} \mathrm{C}$ served as controls. Crabs (10 per experimental condition) were kept for 7 days at the three temperatures in three different aquaria provided with a sandy bottom and well-aerated seawater (salinity of $35 \pm 1 \mathrm{psu}, \mathrm{pH} 8.1$ ), and fed with mussels. Seawater temperature, salinity and $\mathrm{pH}$ were checked daily, whereas seawater was renewed (50\%) every $48 \mathrm{~h}$. 


\subsection{Haemolymph and tissue collection}

At the end of temperature exposure, crabs were anaesthetised on ice for $5 \mathrm{~min}$, and the haemolymph (at least $500 \mu \mathrm{L}$ per crab) was collected from the unsclerotised membrane of the walking legs using a 1-mL plastic syringe, placed in microcentrifuge tubes on ice and diluted (except for glucose assay) 1:2 in an anticoagulant solution of citrate buffer/EDTA ( $\mathrm{NaCl} 0.45 \mathrm{M}$, glucose $0.1 \mathrm{M}$, sodium citrate $30 \mathrm{mM}$, citric acid $26 \mathrm{mM}$, EDTA $10 \mathrm{mM}, \mathrm{pH} 4.6$, stored at $4{ }^{\circ} \mathrm{C}$ ) (Söderhäll and Smith, 1983). For each experimental temperature, 5 pools of haemolymph from 2 crabs each were prepared. Pooling was necessary because individuals did not provide enough haemolymph for analyses. Pooled haemolymph were then divided in four aliquots: two aliquots were immediately used to measure THC and haemocyte proliferation, whereas the remaining two aliquots were processed to measure PO activity in both haemocyte lysate (HL) and cell-free haemolymph $(\mathrm{CFH})$, and $\mathrm{CFH}$ glucose levels. To obtain $\mathrm{CFH}$, pooled haemolymph was immediately centrifuged at $780 \times g$ for $10 \mathrm{~min}$, and the supernatant $(=\mathrm{CFH})$ was collected. To obtain HL, haemocytes were resuspended in distilled water, sonicated at $0{ }^{\circ} \mathrm{C}$ for $1 \mathrm{~min}$, and then centrifuged at $780 \times \mathrm{g}$ for $30 \mathrm{~min}$. Both $\mathrm{CFH}$ and HL were frozen in liquid nitrogen and stored at $80{ }^{\circ} \mathrm{C}$ until analyses.

After haemolymph sampling, the carapace was opened, gills and digestive gland were excised, placed in $2 \mathrm{~mL}$ Eppendorf tubes, frozen and stored at $-80{ }^{\circ} \mathrm{C}$ until processing. Gills and digestive gland were thawed on ice and homogenised in four volumes of $0.1 \mathrm{M}$ Tris- $\mathrm{HCl}$ buffer, $\mathrm{pH} \mathrm{7.5,}$ containing 0.15 M KCl, 0.5 M sucrose, $1 \mathrm{mM}$ EDTA, $1 \mathrm{mM}$ Dithiothreitol (DTT, Sigma) and $40 \mu \mathrm{g}$ $\mathrm{mL}^{-1}$ Aprotinin (Sigma), sonicated for $1 \mathrm{~min}$ at $0{ }^{\circ} \mathrm{C}$ with a Braun Labsonic U sonifier at $50 \%$ duty cycles, and centrifuged at $10,000 \mathrm{~g}$ for $30 \mathrm{~min}$ at $4{ }^{\circ} \mathrm{C}$. Supernatant was collected for enzyme assays. 


\subsection{THC and haemocyte volume determination}

THC was determined by a Model Z2 Coulter Counter electronic particle counter/size analyser (Coulter Corporation, FL, USA). Immediately after sampling, $100 \mu \mathrm{L}$ of pooled haemolymph were added to $19.9 \mathrm{~mL}$ of $0.45 \mu \mathrm{m}$-filtered seawater. THC values were expressed as the number of haemocytes $\left(\times 10^{6}\right) \mathrm{mL}$ haemolymph ${ }^{-1}$, whereas volume of haemocytes were expressed in femtolitres (fL).

\subsection{Haemocyte proliferation}

Haemocyte proliferation was evaluated by a colorimetric method using a commercial kit (Cell proliferation Kit II, Roche). The assay is based on the cleavage of the yellow tetrazolium salt XTT to form an orange formazan dye by metabolic active (viable) cells. Briefly, XTT labelling reagent and electron-coupling reagent were thawed at $37{ }^{\circ} \mathrm{C}$ and mixed immediately before use to obtain the XTT labelling mixture. Two hundred $\mu \mathrm{L}$ of the mixture were added to $400 \mu \mathrm{L}$ of haemolymph and incubated for 4 and $6 \mathrm{hrs}$ in a dark humidified chamber at room temperature. Absorbance at $450 \mathrm{~nm}$ was then recorded on a Beckman 730 spectrophotometer. Results were expressed as optical density per $\mathrm{mL}$ of haemolymph $\left(\mathrm{OD}_{450} \mathrm{~mL}_{\text {haemolymph }}{ }^{-1}\right)$.

\subsection{Haemolymph glucose and total protein concentrations}

Haemolymph glucose levels were measured using a commercial kit (Quantichrom Glucose Assay Kit, BioAssay System). Briefly, $12 \mu \mathrm{L}$ of $\mathrm{CFH}$ were transferred in centrifuge tubes containing $1200 \mu \mathrm{L}$ of the reagent provided with the kit. Tubes were heated in a boiling water bath for $8 \mathrm{~min}$, and then cooled in cold water bath for $4 \mathrm{~min}$. Absorbance at $630 \mathrm{~nm}$ was then recorded on a Beckman 730 spectrophotometer. Results were expressed as mg glucose $\mathrm{mL}$ haemolymph ${ }^{-1}$. CFH protein concentrations were quantified according to the Biuret method (Sigma). Results were expressed as $\mathrm{mg}$ protein $\mathrm{mL}$ haemolymph ${ }^{-1}$. 


\subsection{Phenoloxidase activity assay}

PO activity was measured in both HL and CFH using L-DOPA (3,4-dihydroxy-L-phenylalanine, Sigma) as substrate in a colorimetric assay. One hundred $\mu \mathrm{L}$ of $\mathrm{HL}$ and $\mathrm{CFH}$ were added to $900 \mu \mathrm{L}$ of $1 \mathrm{mg} \mathrm{L}-\mathrm{DOPA} / \mathrm{mL}$ of phosphate buffered saline, $\mathrm{pH}$ 7.2, (PBS: $1.37 \mathrm{M} \mathrm{NaCl}, 0.03 \mathrm{M}$ $\mathrm{KCl}, 0.015 \mathrm{M} \mathrm{KH} 2 \mathrm{PO} 4,0.065 \mathrm{M} \mathrm{Na} 2 \mathrm{HPO} 4)$, and incubated for $30 \mathrm{~min}$ at $37{ }^{\circ} \mathrm{C}$. Absorbance at $490 \mathrm{~nm}$ was then recorded on a Beckman 730 spectrophotometer, and results were expressed as U $\mathrm{mg}_{\text {proteins }}{ }^{-1}$. Protein concentrations in both HL and CFH were quantified according to the Biuret method (Sigma). The specific activity of PO in C. aestuarii has previously been assayed using Nphenylthiourea (10 mM, Fluka) as a inhibitor (Matozzo and Marin, 2010b).

\subsection{SOD activity assay}

Total SOD activity was measured in both gills and digestive gland (see 2.3. section for details regarding supernatant obtainment) in triplicate with the xanthine oxidase/cytochrome $c$ method according to Crapo et al. (1978). The cytochrome $c$ reduction by superoxide anion generated by xanthine oxidase/hypoxanthine reaction was detected at $550 \mathrm{~nm}$ at room temperature. Enzyme activity was expressed as $U$ mg of proteins ${ }^{-1}$, one unit of SOD being defined as the amount of sample producing $50 \%$ inhibition in the assay conditions. The reaction mixture contained $46.5 \mu \mathrm{M}$ $\mathrm{KH}_{2} \mathrm{PO}_{4} / \mathrm{K}_{2} \mathrm{HPO}_{4}(\mathrm{pH}$ 8.6), $0.1 \mathrm{mM}$ EDTA, $195 \mu \mathrm{M}$ hypoxanthine, $16 \mu \mathrm{M}$ cytochrome $c$, and 2.5 $\mu \mathrm{U}$ xanthine oxidase. Protein concentrations in homogenised tissues were quantified according to the Biuret method (Sigma).

\subsection{CAT activity assay}

Gill and digestive gland CAT activity was measured in triplicate following the method of Aebi (1984). Decreases in absorbance of a $50-\mathrm{mM} \mathrm{H}_{2} \mathrm{O}_{2}$ solution $\left(\varepsilon=-0.0436 \mathrm{mM}^{-1} \mathrm{~cm}^{-1}\right)$ in $50 \mathrm{mM}$ phosphate buffer ( $\mathrm{pH} 7.8$ ) and $10 \mu \mathrm{L}$ of tissue supernatant were continuously recorded at $240 \mathrm{~nm}$ at $10 \mathrm{sec}$ intervals for $1 \mathrm{~min}$. Results were expressed in $\mathrm{U} \mathrm{mg}$ of proteins ${ }^{-1}$, one unit of CAT being 
defined as the amount of enzyme that catalysed the dismutation of $1 \mu \mathrm{mol}$ of $\mathrm{H}_{2} \mathrm{O}_{2} \min ^{-1}$. Protein concentrations were quantified according to the Biuret method (Sigma).

\subsection{Statistical analysis}

Data were checked for normal distribution (Shapiro-Wilk's test) and homogeneity of variances

(Bartlett's test). Results were compared using a one-way ANOVA, followed by a post hoc test

(Duncan's test). Values were expressed as means \pm standard error. The STATISTICA 9.0 (StatSoft, Tulsa, OK, USA) software package was used for statistical analyses.

\section{Results}

THC values significantly decreased in crabs kept at $4{ }^{\circ} \mathrm{C}(p<0.05)$ and $30^{\circ} \mathrm{C}(p<0.01)$, when compared with those of control crabs $\left(17^{\circ} \mathrm{C}\right)$ (Fig. 1). No differences were found between crabs kept at $4{ }^{\circ} \mathrm{C}$ and those held at $30{ }^{\circ} \mathrm{C}$. Haemocyte volume did not differ significantly among experimental conditions $\left(293.5 \pm 89.5 \mathrm{fL}\right.$ at $4{ }^{\circ} \mathrm{C}, 278.5 \pm 101.4 \mathrm{fL}$ at $17^{\circ} \mathrm{C}, 291.8 \pm 94.5 \mathrm{fL}$ at 30 ${ }^{\circ} \mathrm{C}$ ). After 4 and 6 hours of haemocyte incubation in XTT labelling mixture, haemocyte proliferation increased significantly $(p<0.05)$ in crabs kept at 4 and $30{ }^{\circ} \mathrm{C}$, when compared with that of crabs held at $17^{\circ} \mathrm{C}$ (Fig. 2).

Although a slight increase in $\mathrm{CFH}$ glucose levels was observed in crabs kept at $30{ }^{\circ} \mathrm{C}$, no significant differences were recorded among experimental conditions (Fig. 3). Conversely, total protein concentration significantly $(p<0.05)$ reduced in $\mathrm{CFH}$ of crabs maintained at $30{ }^{\circ} \mathrm{C}(88 \pm$ $11.04 \mathrm{mg} \mathrm{mL}$ haemolymph $\left.{ }^{-1}\right)$, with respect to that of crabs kept at $4{ }^{\circ} \mathrm{C}(104.26 \pm 8.72 \mathrm{mg} \mathrm{mL}$ haemolymph $\left.{ }^{-1}\right)$ and $17^{\circ} \mathrm{C}\left(107.36 \pm 11.04 \mathrm{mg} \mathrm{mL} \mathrm{haemolymph}{ }^{-1}\right)$ (Fig. 4).

A significantly higher PO activity was recorded in $\mathrm{CFH}$ from crabs kept at $4{ }^{\circ} \mathrm{C}(p<0.05)$ and $30{ }^{\circ} \mathrm{C}(p<0.01)$, when compared to the control group of crabs maintained at $17{ }^{\circ} \mathrm{C}$ (Fig. 5). 230 Conversely, PO activity did not differ significantly in HL from crabs kept at the three experimental temperatures (Fig. 5). 
With regard to antioxidant enzyme activities, a significant $(p<0.05)$ decrease in CAT activity was observed in gills from crabs maintained at $4{ }^{\circ} \mathrm{C}$, when compared to that of crabs kept at 17 and $30{ }^{\circ} \mathrm{C}$ (Table 1). No other significant variations in either CAT and SOD activities were recorded in the gill and digestive gland tissues of crabs held at the three experimental temperatures.

\section{Discussion}

It has previously been reported that variations in environmental parameters (e.g., temperature, salinity, oxygen) can influence immune parameters in Crustacea, causing a reduction in immunecompetence (Le Moullac and Haffner, 2000). In the present study, a suite of biomarkers, both cellular and biochemical, were used to evaluate effects of differing temperatures on the crab $C$. aestuarii. Among the available immunomarkers, THC is considered to be a good indicator of stress in Crustacea (Le Moullac and Haffner, 2000). This study clearly demonstrated that temperatures at both the lower and upper extreme for the Lagoon of Venice significantly reduced THC in $C$. aestuarii. A decrease in the number of circulating haemocytes in Crustacea is generally considered a consequence of haemocyte immobilization in gills (or other tissues), as demonstrated in mercuryexposed prawns (Victor et al., 1990) and in crabs after bacterial infection (Martin et al., 2000; Burnett et al., 2006). A similar consequence can be hypothesised for temperature-stressed crabs in the present study. However, further studies -mainly histological - are necessary to support this hypothesis. In $C$. maenas, animals maintained at $5{ }^{\circ} \mathrm{C}$ (a temperature close to the extreme values in winter) and $20{ }^{\circ} \mathrm{C}$ (a temperature close to the extreme values in summer) showed THC values significantly lower than those of animals kept at $10^{\circ} \mathrm{C}$ (Brockton and Smith, 2008). Increases in water temperature were shown to rise markedly THC in $C$. maenas, probably owing to the release of haemocytes from hematopoietic organs (Truscott and White, 1990). In the spiny lobster, Panulirus interruptus, both cooling rates $\left(3{ }^{\circ} \mathrm{C} / \mathrm{h}\right.$ and $\left.1.5^{\circ} \mathrm{C} / \mathrm{h}\right)$ applied to lower water temperature from 19 to $4{ }^{\circ} \mathrm{C}$ caused a significant decrease in THC (Gomez-Jimenez et al., 2000). Prawns ( $M$. 
animals reared at $20-21{ }^{\circ} \mathrm{C}$ and $33-34^{\circ} \mathrm{C}$ (Cheng and Chen, 2000). Low temperature $\left(18{ }^{\circ} \mathrm{C}\right)$ caused

a significant drop in THC in Penaeus stylirostris compared to prawns kept at $27{ }^{\circ} \mathrm{C}$ (Le Moullac and Haffner, 2000). In shrimps (Litopenaeus vannamei) transferred to $32{ }^{\circ} \mathrm{C}$, $\mathrm{THC}$ values decreased significantly by $40 \%$ after $24 \mathrm{~h}$ when compared to those of animals kept at $28{ }^{\circ} \mathrm{C}$ (control), whereas THC of shrimps transferred to $20{ }^{\circ} \mathrm{C}$ decreased significantly by $12 \%$ and $16 \%$ after 24 and $48 \mathrm{~h}$, respectively (Cheng et al., 2005).

It has been demonstrated that crustacean haemocytes can divide in haemolymph, and that proliferation can increase significantly after mitogenic or infectious stimulation (Sequeira et al., 1996). Interestingly, the present study demonstrated that extreme temperatures caused a significant increase in haemocyte proliferation, suggesting that the proliferative rate of circulating haemocytes increased in temperature-stressed crabs in order to compensate partially for the reduction in the number of circulating haemocytes. Similar results were recorded in Crustacea subject to different stress conditions. For example, Sequeira et al. (1996) reported a significant increase in the proliferation of circulating haemocytes in Penaeus japonicus following injection with lipopolysaccharide, and a six-fold increase in the percentage of proliferating haemocytes was also observed in animals infected with Fusarium spp. Likewise, bacteria injection caused a reduction in THC values and a significant increase in haemocyte proliferation in $C$. aestuarii (Matozzo et al., 2011).

In Crustacea, an increase in haemolymph glucose levels is considered a response to stress (Hall and van Ham, 1998; Lorenzon, 2005). The release of glucose into the haemolymph is mediated by the crustacean hyperglycaemic hormone $(\mathrm{CHH})$ through the mobilisation of intracellular glycogen stores (Stentiford et al., 2001). Hyperglycaemia has been documented in Crustacea following exposure to a variety of stressors, such as emersion (Durand et al., 2000), cold shock (Kuo and Yang, 1999), anoxia and carbon dioxide (Hall and van Ham, 1998), nitrite (Yildiz and Benli, 2004), and pollutants (Lorenzon et al., 2000). In the present study, extreme temperature did not cause significant variations in glucose levels in haemolymph of C. aestuarii. Likewise, Chang et al. 
(1998) demonstrated that emersion was a potent stimulator of haemolymph $\mathrm{CHH}$ in Homarus

americanus, whereas temperature and salinity variations were less effective. Conversely, increases in water temperature resulted in increased blood $\mathrm{CHH}$ in Cancer pagurus (Wilcockson et al., 2002).

In Uca minax, a temperature value of $10{ }^{\circ} \mathrm{C}$ caused a significant decrease in haemolymph glucose levels (Dean and Vernberg 1965), whereas in P. interruptus, increases in temperature from $20{ }^{\circ} \mathrm{C}$ to

$27{ }^{\circ} \mathrm{C}$ induced an increase in haemolymph glucose levels (Ocampo et al., 2003). Powell and Rowley (2008) suggested that increases in haemolymph glucose levels may be due to the mobilisation of glucose from haepatopancreas and/or muscles in stressed crabs. Results of the present study demonstrated that the extreme temperatures tested did not elicit significant variations in haemolymph glucose concentrations. As a consequence, a temperature-induced mobilisation of glucose from haepatopancreas and/or muscles can be excluded in C. aestuarii, on the basis of these preliminary results at least.

In the present study, a significant decrease in haemolymph total protein levels was recorded in $C$. aestuarii maintained at $30{ }^{\circ} \mathrm{C}$. In $H$. americanus, significant differences in total protein concentrations were observed between animals kept at $6{ }^{\circ} \mathrm{C}$ and those maintained at $15{ }^{\circ} \mathrm{C}$ (Lorenzon et al., 2007). In the present study, it can be hypothesised that crabs maintained at $30{ }^{\circ} \mathrm{C}$ used haemolymph proteins to cope with high temperature, considering that proteins are the primary source of energy in Crustacea (Helland et al., 2003; Sanchez-Paz et al., 2007). The results obtained suggested that $C$. aestuarii exploited proteins as an immediate energy source during high temperature stress, while it accumulated glucose in haemolymph to be used after.

The role of PO in immune reactions of Crustacea has extensively been reviewed by Söderhäll and Cerenius (1998). The zymogen proPO occurs within the granulocytes of decapods; upon activation by limited proteolysis, the active form of the enzyme - which is responsible for melanin deposition - can be released into the haemolymph (Cerenius and Söderhäll, 2004). We chose to measure PO activity in both $\mathrm{CFH}$ and $\mathrm{HL}$ of $C$. aestuarii to follow enzyme variation pattern in both media. In the present study, both the lowest and highest temperature tested caused a significant 
increase of PO activity in crab $\mathrm{CFH}$, whereas no significant variations in $\mathrm{PO}$ activity were recorded

311 in HL. Lobsters (P. interruptus) reared at $4{ }^{\circ} \mathrm{C}$ had significantly lower PO activity as compared to

312 the lobsters reared in 14 and $19{ }^{\circ} \mathrm{C}$ (Gomez-Jimenez et al., 2000). In a recent study, shrimps

313 (Litopenaeus vannamei) transferred to $32{ }^{\circ} \mathrm{C}$ showed significant decreases in PO activity after 24-

$31496 \mathrm{~h}$, when compared to that of control animals $\left(28^{\circ} \mathrm{C}\right)(\mathrm{Cheng}$ et al., 2005). In the same study,

315 shrimps transferred to $20^{\circ} \mathrm{C}$ showed a PO activity decreased significantly by $12 \%$ and $14 \%$ after 24

316 and $48 \mathrm{~h}$, with respect to control shrimps. It is well known that crustacean haemocytes, mainly

317 granulocytes, contain high levels of PO, which can be secreted by haemocytes into the haemolymph

318 where it is involved in melanin deposition around the damaged tissues (Cerenius and Soderhall,

319 2004). We have recently demonstrated that haemocytes from $C$. aestuarii are also involved in PO

320 production (Matozzo and Marin, 2010b). Although a positive correlation between THC and PO

321 activity is generally reported in the literature (see Cheng et al., 2005 and cited references), the

322 present study clearly demonstrated that PO activity increased when THC decreased. We can

323 hypothesise that increased PO activity in haemolymph from temperature-stressed crabs was a

324 physiological response of animals to compensate for lower $\mathrm{THC}$, in order to increase

325 immunosurveillance in both haemolymph and peripheral tissues, corroborating findings by Hauton

326 et al. (1997). They suggested that fluctuations in PO activity are not attributable to changes in

327 haemocyte number. Indeed, P. stylirostris increased its PO activity but decreased its THC following

328 hypoxia stress (Le Moullac et al., 1998). A negative correlation between PO activity and THC was

329 also observed in C. maenas (Hauton et al., 1995) and in the common shrimp Crangon crangon

330 (Smith and Johnston, 1992). Nevertheless, the increase in haemolymph PO activity observed in the

331 present study could be caused by a change in haemocyte sub-populations, as a marked PO activity

332 was found in granulocytes from C. aestuarii, but not in hyalinocytes (Matozzo and Marin, 2010b).

333 Further studies are needed to support this hypothesis.

334 Reactive oxygen species (ROS), such as superoxide anion $\left(\mathrm{O}_{2}{ }^{-}\right)$, hydrogen peroxide $\left(\mathrm{H}_{2} \mathrm{O}_{2}\right)$, and 335 hydroxyl radical $\left(\mathrm{OH}^{\prime}\right)$, can be dangerous for organisms, being able to induce oxidative damage to 
lipids, DNA and other key molecules (Halliwell and Gutteridge, 1999). Organisms have developed

antioxidant systems to protect their biological structures from ROS-mediated damage (Halliwell and Gutteridge, 1999). In antioxidant systems, SOD is the first and most important defence line, as it catalyses the dismutation of the superoxide anion into molecular oxygen and hydrogen peroxide. CAT, with glutathione peroxidase (GPx), is the most important scavenger of $\mathrm{H}_{2} \mathrm{O}_{2}$ in cells. In our study, the lowest temperature caused a significant reduction of CAT activity in gills. Results obtained in C. aestuarii are difficult to explain, mainly considering that information concerning temperature effects on crustacean antioxidant enzyme activities are scarce. In the shrimp $L$. vannamei transferred to $32{ }^{\circ} \mathrm{C}$, haemocyte SOD activity decreased significantly after $24 \mathrm{~h}$, when compared to control animal $\left(28{ }^{\circ} \mathrm{C}\right)$; for shrimps transferred to $20^{\circ} \mathrm{C}$, SOD activity decreased significantly by $20 \%$ both after 24 and $48 \mathrm{~h}$ (Cheng et al., 2005). In the mud crab Scylla serrata, the activities of both SOD and CAT in gills were higher in summer and lower in winter (Kong et al., 2008). On the basis of the results obtained, it can be hypothesised that $C$. aestuarii is more susceptible to oxidative stress (with regard to CAT activity at least) when lower seawater temperatures are reached.

In conclusion, the present study demonstrated that both the lowest and the highest temperature tested influenced immune parameters in crabs. Conversely, responses provided by antioxidant enzymes were not indicative of particular differences due to variation in temperature values. In any case, the present study also indicated that $C$. aestuarii modulated its cellular and biochemical parameters in order to cope with temperature (see for example haemocyte proliferation and CFH PO activity). This suggested that when crabs suffer temperature stress in the environment, they can respond promptly by modulating immune parameters. However, both results of the present study and those from the literature suggest differing immunemodulation patterns in crustacean species depending on their thermal optimum. 
363

364

365

366

Fig. 1. Effects of temperature on THC, expressed as number of haemocytes $\left(\times 10^{6}\right) \mathrm{mL}$ haemolymph ${ }^{-1}$, in $C$. aestuarii. Values are means \pm s.e.; $\mathrm{n}=5, * p<0.05, * * p<0.01$.

Fig. 2. Effects of temperature on haemocyte proliferation, expressed as $\mathrm{OD}_{450} \mathrm{~mL}_{\text {haemolymph }}{ }^{-1}$, in C. aestuarii. Values are means \pm s.e.; $\mathrm{n}=5,{ }^{*} p<0.05$.

Fig. 3. Effects of temperature on haemolymph glucose levels, expressed as $\mathrm{mg}$ glucose $\mathrm{mL}$ haemolymph ${ }^{-1}$, in $C$. aestuarii. Values are means \pm s.e.; $\mathrm{n}=5$.

Fig. 4. Effects of temperature on haemolymph total protein concentrations, expressed as $\mathrm{mg} \mathrm{ml}$ haemolymph ${ }^{-1}$, in $C$. aestuarii. Values are means \pm s.e.; $\mathrm{n}=5, * p<0.05$.

Fig. 5. Effects of temperature on PO activity, expressed as $U \mathrm{mg}$ proteins ${ }^{-1}$, in haemocyte lysate (HL) and cell-free haemolymph $(\mathrm{CFH})$ of $C$. aestuarii. Values are means \pm s.e.; $\mathrm{n}=5,{ }^{*} p<0.05,{ }^{* *} p$ $<0.01$. 


\section{References}

Aebi, H., 1984. Catalase in vitro. Methods in Enzymology 105,121-126.

Bauchau, A.G., 1981. Crustaceans. In: Ratcliffe, N.A., Rowley, A.F. (Eds.), Invertebrate Blood Cells, vol. 2. Academic Press, London, pp 385-420.

Brockton, V., Smith, V.J., 2008. Crustin expression following bacterial injection and temperature change in the shore crab, Carcinus maenas. Developmental and Comparative Immunology $32,1027-1033$.

Burnett, L.E., Holman, J.D., Jorgensen, D.D., Ikerd, J.L., Burnett, K.G., 2006. Immune defense reduces respiratory fitness in Callinectes sapidus, the Atlantic Blue crab. Biological Bulletin $211,50-57$.

Cerenius, L., Söderhäll, K., 2004. The prophenoloxidase-activating system in invertebrates. Immunological Reviews 198, 116-126.

Chang, E.S., Keller, R., Chang, S.A., 1998. Quantification of crustacean hyperglycemic hormone by ELISA in hemolymph of the lobster, Homarus americanus, following various stress. General and Comparative Endocrinology 111, 359-366.

Cheng. W., Chen. J.C., 2000. Effect of pH, temperature and salinity on immune parameters of the freshwater prawn Macrobrachium rosenbergii. Fish \& Shellfish Immunology 10, 387-391.

Cheng, W., Wang, L.-U., Chen, J-C. 2005. Effect of water temperature on the immune response of white shrimp Litopenaeus vannamei to Vibrio alginolyticus. Aquaculture 250, 592-601

Chisholm, J.R.S., Smith, V.J., 1992. Antibacterial activity in the haemocytes of the shore crab, Carcinus maenas. Journal of Marine Biological Association U. K. 72, 529-542.

Crapo, J.D., McCord, J.M., Fridovich, I., 1978 Preparation and assay of superoxide dismutase. Methods in Enzymology 53, 382-393.

Dean, J.M., Vernberg, F.J., 1965. Effects of temperature acclimation on some aspects of carbohydrate metabolism in decapod crustacea. Biological Bulletin 129, 87-94. 
Durand, F., Devillers, N., Lallier, F.H., Regnault, M., 2000. Nitrogen excretion and change in blood components during emersion of the subtidal spider crab Maia squinado (L.). Comparative Biochemistry and Physiology 127A, 259-271.

Gomez-Jimenez, S., Uglow, R.F., Gollas-Galvan, T., 2000. The effects of cooling and emersion on total hemocyte count and phenoloxidase activity of the spiny lobster Palinurus interruptus. Fish \& Shellfish Immunology 10, 631-635.

Hall, M.R., van Ham, E.H., 1998. The effects of different types of stress on blood glucose in the giant tiger prawn Penaeus monodon. Journal of the World Aquaculture Society 29, 290-299.

Halliwell, B., Gutteridge, J.M.C., 1999. Antioxidant defences. In: Free Radicals in Biology and Medicine. Oxford University Press Inc, New York, pp 105-245.

Hauton, C., Hawkins, L.E., Williams, J.A. 1995. Circatidal rhythmicity in the activity of phenoloxidase enzyme in the common shore crab (Carcinus maenas). Comparative Biochemistry and Physiology 111B, 374-352.

Hauton, C., William, J.A., Hawkins, L.E., 1997. In situ variability in phenoloxidase activity in the shore crab, Carcinus maenas (L.). Comparative Biochemistry and Physiology 117B, 267271.

Hong, M., Chen, L., Sun, X., Gu, S., Zhang, L., Chen, Y., 2007. Metabolic and immune responses in Chinese mitten-handed crab (Eriocheir sinensis) juveniles exposed to elevated ambient ammonia. Comparative Biochemistry and Physiology 145C, 363-369.

Hsu, S.W., Chen, J,C., 2007. The immune response of white shrimp Penaeus vannamei and its susceptibility to Vibrio alginolyticus under sulfide stress. Aquaculture 271, 61-69.

Kong, X., Guizhong, W., Shaojing, L., 2008. Seasonal variations of ATPase activity and antioxidant defenses in gills of the mud crab Scylla serrata (Crustacea, Decapoda). Marine Biology 154, 269-276.

Kuo, C.M., Yang, Y.H., 1999. Hyperglycemic responses to cold shock in the freshwater giant prawn, Macrobrachium rosenbergii. J. Comp. Physiol. 169B, 49-54. 
Le Moullac, G., Soyez, C., Saulnier, D., Ansquer, D., Avarre, J.C., Levy, P., 1998. Effect of hypoxia stress on the immune response and the resistance to vibriosis of the shrimp Penaeus stylirostris. Fish \& Shellfish Immunology 8, 621-629.

Le Moullac, G., Haffner, P, 2000. Environmental factors affecting immune responses in Crustacea. Aquaculture, 191, 121-131.

Lorenzon, S., 2005. Hyperglicemic stress response in Crustacea. Invertebrate Survival Journal 2, $132-141$.

Lorenzon, S., Francese, M., Ferrero, E.A., 2000. Heavy metal toxicity and differential effects on the hyperglycemic stress response in the shrimp Palaemon elegans. Archives of Environmental Contamination and Toxicology 39, 167-176.

Martin, G.G., Quintero, M., Quigley, M., Khosrovian, H., 2000. Elimination of sequestered material from the gills of decapod crustaceans. Journal of Crustacean Biology 20, 209-217.

Matozzo, V., Marin, M.G., 2010a. First cytochemical study of haemocytes from the crab Carcinus aestuarii (Crustacea, Decapoda). European Journal of Histochemistry 54, 44-49.

Matozzo, V., Marin, M.G., 2010b.The role of haemocytes from the crab Carcinus aestuarii (Crustacea, Decapoda) in immune responses: a first survey. Fish \& Shellfish Immunology $28,534-541$.

Matozzo, V., Gallo, C., Monari M., Marin M.G., 2011. Cellular and biochemical parameters in the crab Carcinus aestuarii after experimentally-induced stress: effects of bacteria injection, leg ablation and bacteria injection/leg ablation combination. Journal of Experimental Marine Biology and Ecology 398, 18-25.

Ocampo, L., Patiño, D., Ramirez, C., 2003. Effect of temperature on haemolymph lactate and glucose concentration in spiny lobster Palinurus interruptus during progressive hypoxia. Journal of Experimental Marine Biology and Ecology 296, 71-77.

Paterson, W.D., Stewart, J.E., 1973. In vitro phagocytosis by hemocytes of the american lobster Homarus americanus. Journal of the Fisheries Research Board of Canada 31, 1051-1056. 
Powell, A., Rowley, A.F., 2008. Tissue changes in the shore crab Carcinus maenas as a result of infection by the parasitic barnacle Sacculina carcini. Diseases of Aquatic Organisms 80, 7579.

Roman, J., Palumbi, S.R., 2004. A global invader at home: population structure of the green crab, Carcinus maenas, in Europe. Molecular Ecology 13 , 2891-2898.

Romano, N., Zeng, C., 2009. Subchronic exposure to nitrite, potassium and their combination on survival, growth, total haemocyte count and gill structure of juvenile blue swimmer crabs, Portunus pelagicus. Ecotoxicoltoy and Enivornmental Safety 72, 1287-1295.

Sequeira, T., Tavares, D., Arala-Chaves, M., 1996. Evidence for circulating hemocyte proliferation in the shrimp Penaeus japonicus. Developmental and Comparative Immunology 20, 97-104.

Smith, V.J., Johnston, P.A., 1992. Differential haemotoxic effect of PCB congeners in the common shrimp Crangon crangon. Comparative Biochemistry and Physiology 101C, 641-649.

Söderhäll, K., Cerenius, L., 1998. Role of the prophenoloxidase-activating systems in invertebrate immunity. Current Opinion in Immunology 10, 23-28.

Söderhäll, K., Smith, V.J., 1983. Separation of the hemocyte populations of Carcinus maenas and other marine decapods and prophenoloxidase distribution. Developmental and Comparative Immunology 7, 229-239.

Steenbergen, J.F., Steenbergen, S.M., Schapiro, H.C., 1978. Effects of temperature on phagocytosis in Homarus americanus. Aquaculture 14, 23-30.

Stentiford, G.D., Chang, E.S., Chang, S.A., Neil, D.M., 2001. Carbohydrate dynamics and the crustacean hyperglycemic hormone $(\mathrm{CHH})$ : effects of parasitic infection in Norway lobsters (Nephrops norvegicus). General and Comparative Endocrinology 121, 13-22.

Truscott, R., White, K.N., 1990. The influence of metal and temperature stress on the immune system of crabs. Functional Ecology 4, 455-461. 
Vargas-Albores, F., Baltazar, P.H., Clark, G.P., Barajas, F.M., 1998. Influence of temperature and salinity on the yellowlegs shrimp, Penaeus californiensis Holmes, prophenoloxidase system. Aquaculture Research 29, 549-553.

Victor, B., Narayanan, M., Jones Nelson, D., 1990. Gill pathology and hemocyte response in mercury exposed Macrobrachium idae (Heller). Journal of Environmental Biology 11, 6165.

Wilcockson, D.C., Chung, J.S., Webster, S.G., 2002. Is crustacean hyperglycemic hormone precursor-related peptide a circulating neurohormone in crabs? Cell and Tissue Research 307,129-38.

Yamada, S.B., Hauck, L., 2001. Field identification of the European green crab species: Carcinus maenas and Carcinus aestuarii. Journal of Shellfish Research 20, 905-912.

Yildiz, H.Y., Benli, A.C.K., 2004. Nitrite toxicity to crayfish, Astacus leptodactylus, the effects of sublethal nitrite exposure on hemolymph nitrite, total hemocyte counts, and hemolymph glucose. Ecotoxicology and Environmental Safety 59, 370-375. 


\section{HIGHLIGHTS}

- Effects of temperature to the crab Carcinus aestuarii were evaluated.

- Various cellular and biochemical biomarkers were measured.

- Both high and low temperature influenced crab biological responses. 
Tab. 1. SOD and CAT activities, expressed as $U \mathrm{mg}^{\text {proteins }}{ }^{-1}$, in gills and digestive gland from crabs $(C$. aestuarii) kept at different temperatures. Values are means \pm s.e.; $\mathrm{n}=10$. Asterisk denotes significant differences with respect to both control $\left(17^{\circ} \mathrm{C}\right)$ and $30^{\circ} \mathrm{C}$-exposed crabs; $* p<0.05$.

Gills

Digestive gland

\begin{tabular}{|c|c|c|c|c|}
\hline $\begin{array}{l}\text { Experimental } \\
\text { temperatures }\end{array}$ & $\begin{array}{c}\text { SOD } \\
\text { activity }\end{array}$ & $\begin{array}{c}\text { CAT } \\
\text { activity }\end{array}$ & $\begin{array}{c}\text { SOD } \\
\text { activity }\end{array}$ & $\begin{array}{c}\text { CAT } \\
\text { activity }\end{array}$ \\
\hline $4{ }^{\circ} \mathrm{C}$ & $2.22 \pm 0.24$ & $4.77 \pm 1.59 *$ & $0.81 \pm 0.18$ & $1.97 \pm 0.49$ \\
\hline $17^{\circ} \mathrm{C}$ & $1.91 \pm 0.27$ & $8.05 \pm 2.12$ & $0.63 \pm 0.19$ & $2.64 \pm 1.37$ \\
\hline $30{ }^{\circ} \mathrm{C}$ & $2.10 \pm 0.27$ & $10.68 \pm 1.86$ & $0.97 \pm 0.39$ & $2.22 \pm 1.07$ \\
\hline
\end{tabular}




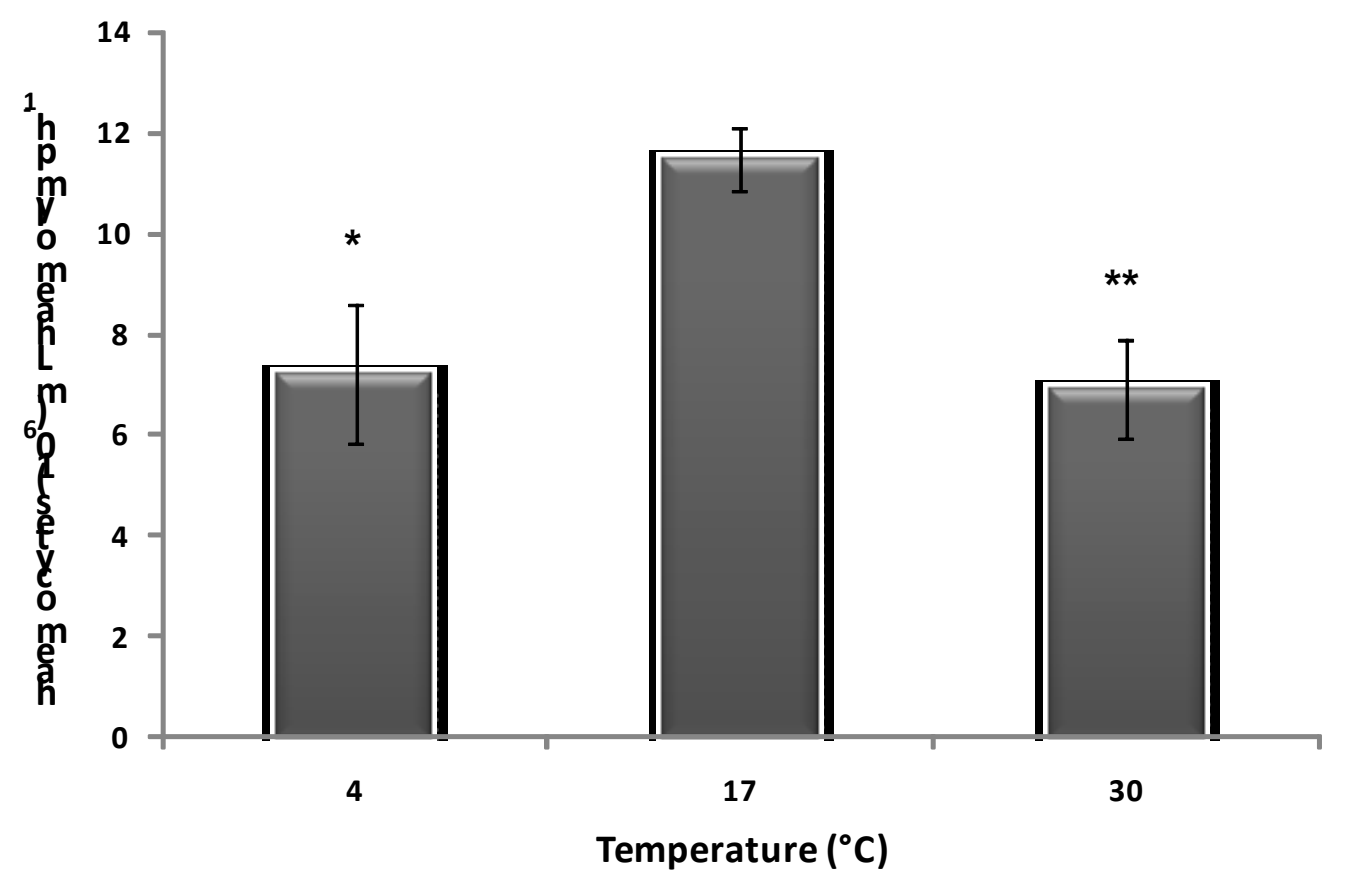

Fig. 1

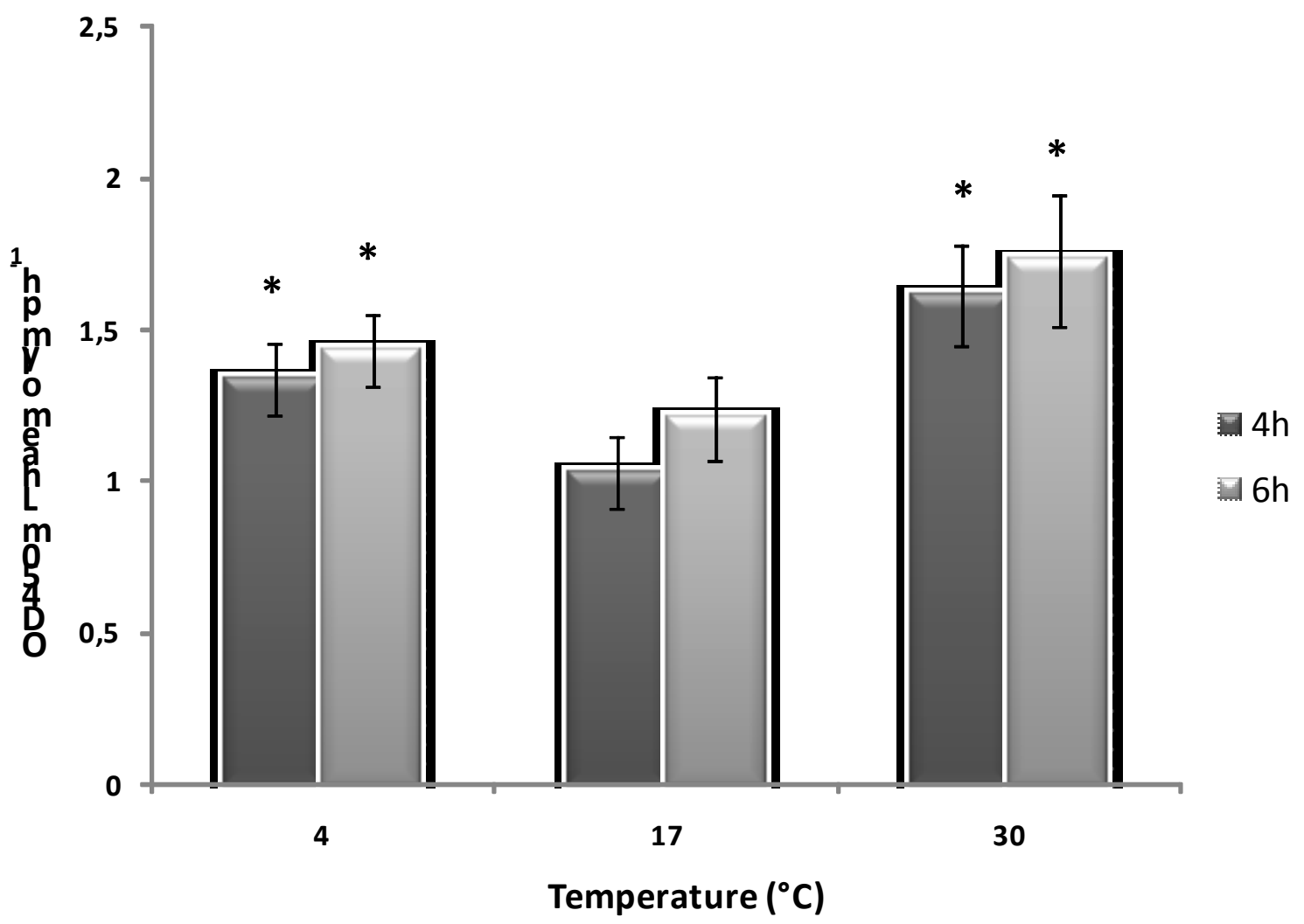

Fig. 2 


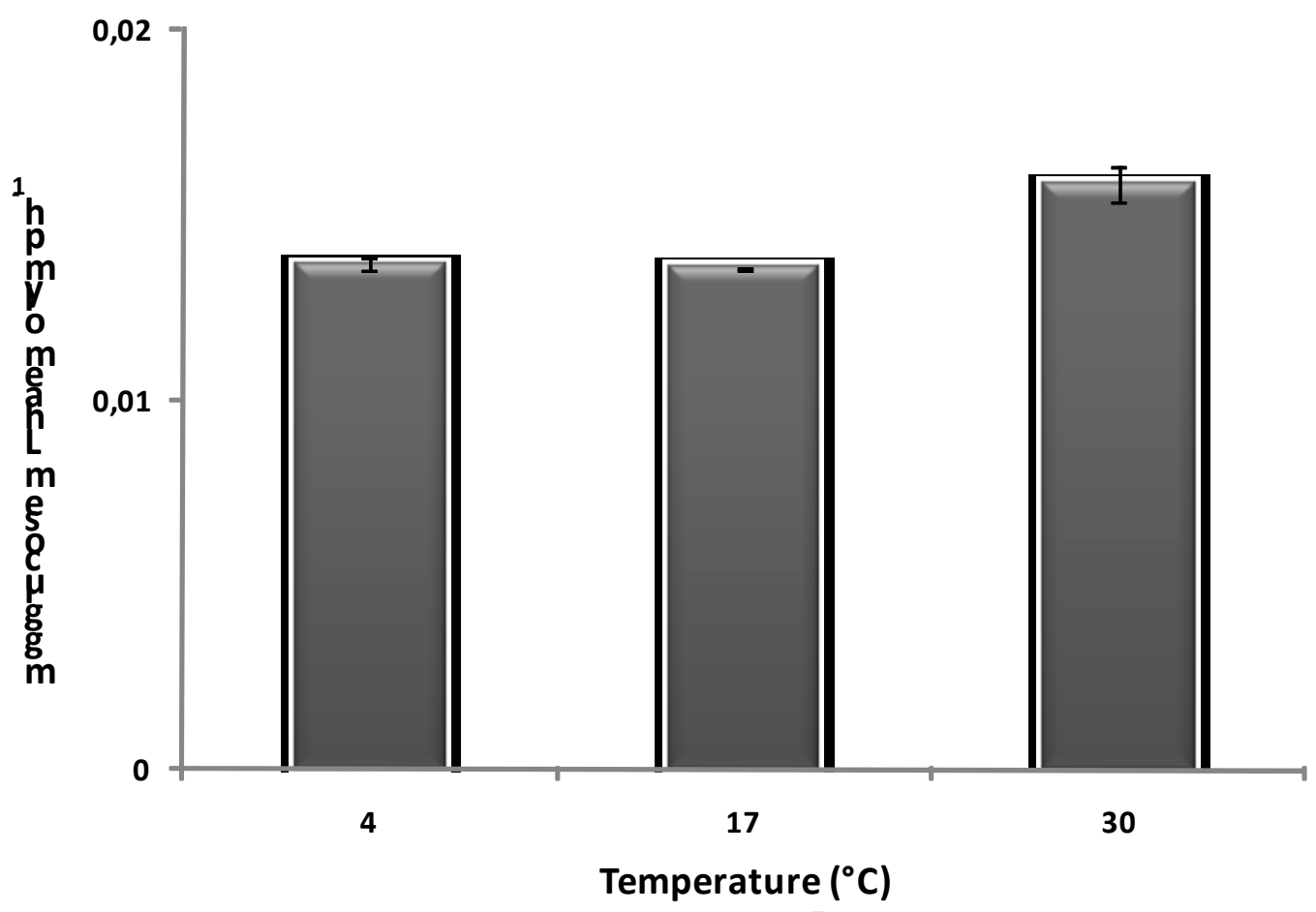

Fig. 3

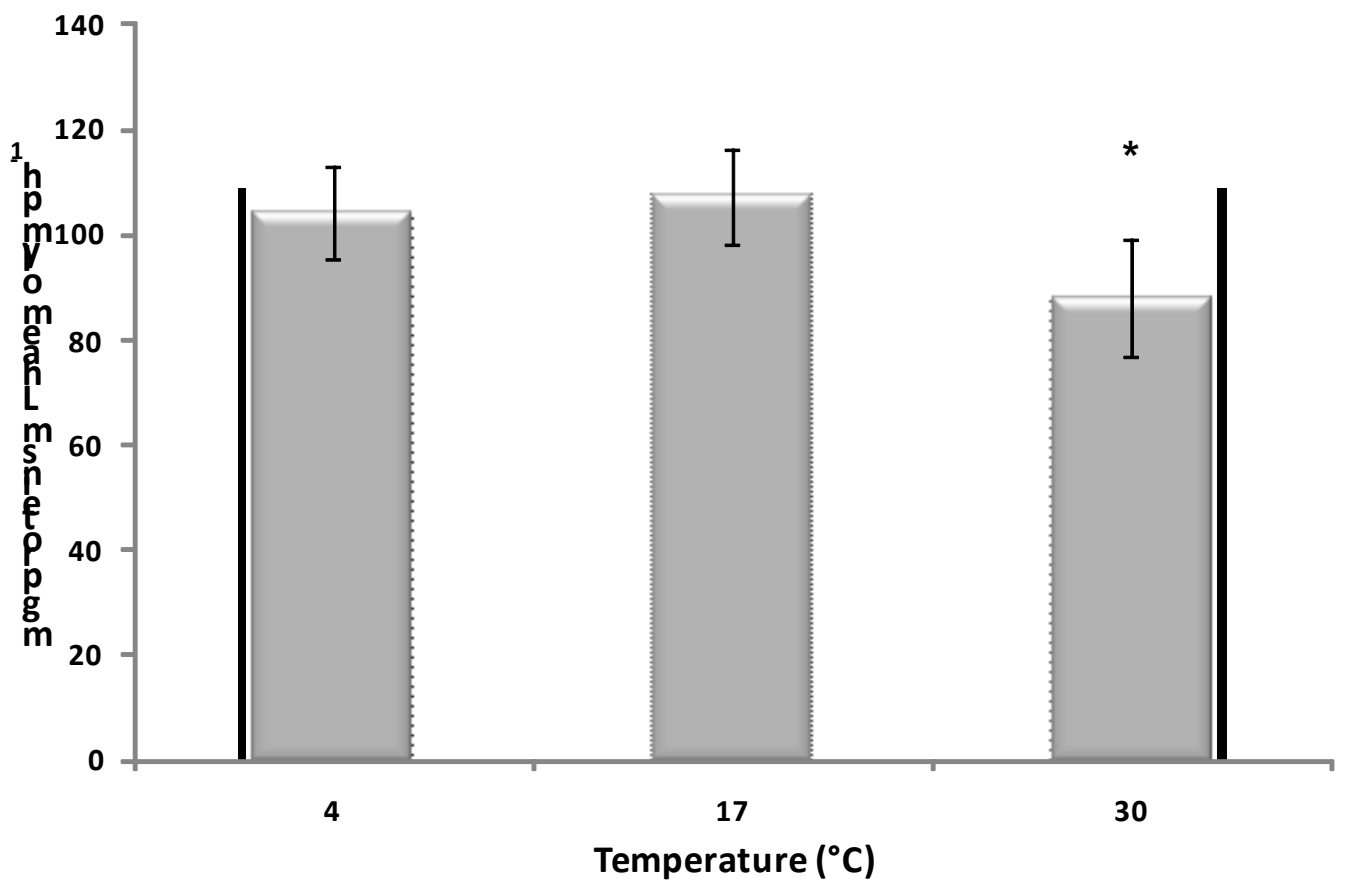

Fig. 4 


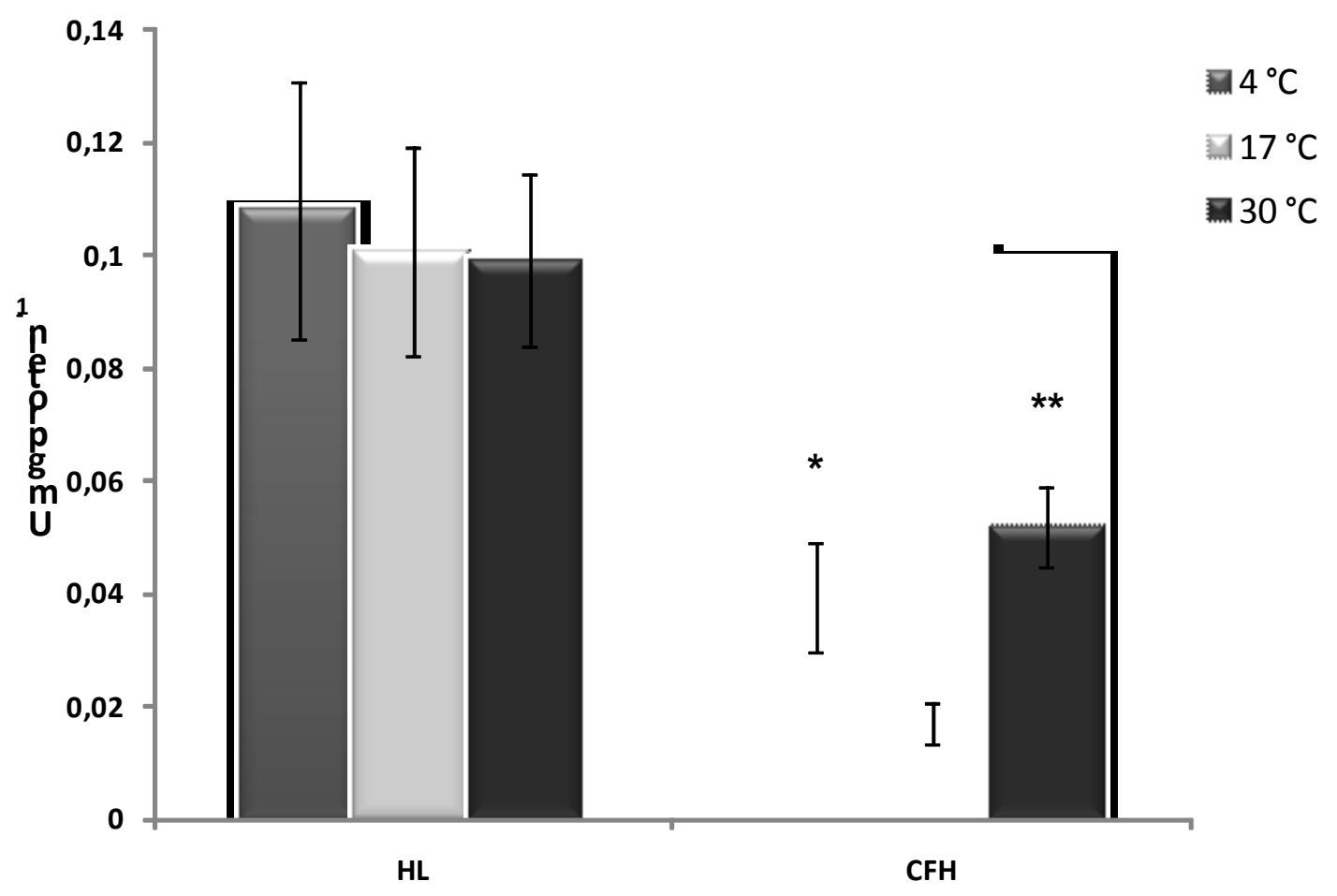

Fig. 5 